\title{
The Influence of Work Motivation on Turnover Intention among Gen Y Employees
}

\author{
Komalaa Naaidu Parthiban, Mastura Mahfar
}

\begin{abstract}
Work motivation has been identified as an influential variable associated with turnover intention. However, only a few studies have examined its prediction on turnover intention. This study discussed the influences of work motivational factors (compensation, nature of job and interpersonal relationship) on turnover intention among Gen $Y$ employees. The sampling method used in this study was stratified random sampling and the sample size was 108 employees in the manufacturing company. The results indicated that the level of work motivation among Gen $Y$ employees is moderate, while the level of turnover intention is high. The result also shows that there is no significant difference of work motivation based on gender among Gen Y employees. The multiple regression results indicated that the three factors of work motivation such as interpersonal, compensation, and nature of the job did not have significant influence on turnover intentions of Gen $Y$ employees. This research concludes with the recommendations for the employees and future works for researcher.
\end{abstract}

Keywords: work motivation, compensation, nature of job, interpersonal relationship, turnover intention

\section{INTRODUCTION}

In the new global economy, the working environment is changing so rapidly where the employer and employee have to catch up with many global knowledge and skills. One of the widest problems that need higher knowledge to overcome in workforce today is the increasing turnover rate among employees. Employee turnover is the rotation of workers around the labour market between firms, jobs and occupations and between the states of employment and unemployment (1). The term "turnover" is defined as the ratio of the number of organizational members who have left during the period being considered divided by the average number of people in that organization during the period. This problem has been rising so rapidly among Gen-Y who occupies today's workforce where it threatens the job motivation, performance, and productivity (23). In order to curb this problem among Gen Y, the scholars, researchers, academicians and even employers have come out with many researches to develop a solution through training and development to eradicate turnover rate in an organization. They have found a driving force beyond this solution is work motivation (19). Furthermore, work motivation is an important phenomenon for both scholars and practitioners to understand the root of any work related problems.

Revised Manuscript Received on October15, 2019

* Correspondence Author

Komalaa Naaidu, Faculty of Social Sciences, Universiti Teknologi Malaysia (UTM), Johor Bahru, Johor, Malaysia. koms.interisland@gmail.com

Mastura binti Mahfar*, Faculty of Social Sciences and Humanities, Universiti Teknologi Malaysia, Johor Bahru, Johor, Malaysia. mastura@utm.my
The discussion on work motivation had derived the scholars to conduct research on this study. There are many studies on work motivation affects turnover rate among employee, for instance, a study has been done on employee motivation at Hyderabad Industries to identify the factors which will motivate employees in Hyderabad industries to retain in the job for longer time. It emphasized the effects of benefits, job promotion and interpersonal relationship towards work motivation (21). In Malaysia, a previous study shows that voluntary turnover intention among generation Y influenced by the satisfaction with payment and fringe, perceived availability of alternative job and job hopping are significant to generation- $Y$ employees' intention to quit (2). This study also provides implication to human resource (HR) managers that generation-Y employees' intention to quit may not be entirely due to HR strategies. Instead, cultural and economic factors play an important role in such decisions. Hence, the author of the study concludes that, salary is the main factor for motivating the generation $\mathrm{Y}$ employees to retain in their organization. On the other hand, other studies indicated that interpersonal relationship and nature of job as the main factor in United States to affect the turnover rate among youths (15). Similarly, theories and models also yield different motivational factors that trigger turnover intention among employees which will be further discussed in chapter two.

Therefore, it is clearly illustrated that interpersonal relationship, nature of job and compensation become the dominating factors in work motivation for curb the employee's turnover rate in past studies. Thus, this research is interested in identifying the root influence of employee turnover in Malaysia by analyzing these factors. Hence, a manufacturing company in Senai, Johor Bahru was selected as the research ground prone to the Human Resource Manager interview conducted recently who declared that the turnover rate among Generation $\mathrm{Y}$ in their company is irrepressible.

\section{Problem Statement}

According to a new employment survey in Malaysia, 93 per cent of respondents are prepared to leave the country in searching of jobs and experience that has dire implications on Malaysia's chronic brain drain (4). If this migration is not come to concern, it might influence the Generation $\mathrm{Y}$ to take the same decision which is to migrate in search for better life in future (25). One of the most quoted statistical facts is that Malaysia has touched a perilous stage in this process of brain drain. From the article Managing Workforce (2006), most perplexing problems confronting migration scholars are the lack of significance of local unemployment and turnover rates in explaining migration. 
Thus, it would be expected that labour turnover variables (such as rates of new hires and layoffs) would play an important part in the explanation of migration. Only the turnover deflection could help the migration stoppable. Therefore, this research is narrowed down to keep the focus on turnover rate in labour force. In current situation, turnover rate is flooding the workforce in Malaysia. Turnover rate is directly caused by work motivation levels of employees (23).

Indeed, a past study found a driving force to curb the turnover problem is work motivation (19). Models of work motivation such as Rational-Economic Model of Work Motivation, Social Model of Work Motivation and Self-actualizing Model of Work Motivation illustrates that there are three main work motivational factors which are compensation, interpersonal relationship and nature of job. These factors have been studied in previous studies on work motivation, however, lack of studies are related with current Gen Y. Today, workforces are occupied by Gen Y and it was expected more 20 years Gen $Y$ will lead the workforce.

In addition, the work motivation is varies according to gender. Females are faced with more obstacles in workplace and have inferior work motivation (18). The female employees tend to take extended time to adapt to new technologies. Hence, the chances of women to quit the job are high compared to men.

In contrast, a break new ground by documenting a previously unstudied phenomenon where compared to men, women have more life goals that make achieving high-power positions at work seem less desirable but equally attainable (10). In relation, other study concludes that there is no significant correlation between gender and employees' work motivation (27). The findings of these studies show inconsistencies of past results and arouses the researcher's interest to identify the difference of work motivation based on gender among Gen Y employees.

Therefore, a null hypothesis has been tested by using independent t- test which posited that:

$H_{o 1}$ : Work motivation has no significant difference based on gender among Gen Y employees.

Apart from that, this study was also conducted to develop a better understanding of how specific work motivational factors (compensation, interpersonal relationship and nature of job) serve as predictors of turnover intention among Gen $\mathrm{Y}$ employees. In line with the importance of studying the turnover intention, a number of studies have offered the empirical evidence on the association between work motivational factors and turnover intention. A study which was conducted at Hyderabad Industries revealed that work motivation (benefits, job promotion and interpersonal relationship) had been associated with employees' turnover intentions (21). Meanwhile, only 29 per cent of millennials are engaged at work, that means only about three in 10 are emotionally and behaviourally connected to their job and company (9). Turnover rate is increasing seriously and concern among employers in USA especially in terms of nature of job (23).

In Malaysia, voluntary turnover intention among Gen Y had been influenced by the satisfaction with payment and fringe, perceived availability of alternative job and job hopping (2). On the other hand, interpersonal relationship and nature of job as the main factors in United States which affect the turnover rate among youths (15). Therefore, it is clearly illustrated that interpersonal relationship, nature of job and compensation are considered the dominating factors in work motivation for curbing the employee's turnover rate in past studies. However, the findings of previous studies were limited because most of them reported only correlational results. Additonally, the previous studies had conflicting results regarding the association between work motivational factors and turnover intention.

In the context of location of study, this research specifically selected Johor because the state remains the country's top investment destination for the manufacturing sector and continues to attract strong interest from domestic and foreign investors (24). Furthermore, the company selected has been undergone a serious turnover issue in the company. According to an interview with Human Resource Manager in one of the manufacturing in Johor Bahru, turnover is flooding the company especially in operational level employees.

Thus, it is crucial to fully understand turnover intention, mainly in terms of exploring the links between work motivational factors and turnover intention among Gen Y employees. The turnover intention is treated as a dependent variable. The independent variables are presented by the work motivational factors. Three hypotheses have been tested by employing multiple linear regression (MLR) method which posited that:

$\begin{aligned} & H_{a 2}: \begin{array}{l}\text { Compensation has a significantly negative } \\ \text { influence on turnover intention among }\end{array} \\ & \text { Gen Y employees. } \\ & H_{a 3}: \quad \begin{array}{l}\text { Nature of the job has a significantly positive } \\ \text { influence on turnover intention among Gen Y } \\ \text { employees. } \\ \text { Interpersonal relationship has a significantly } \\ \text { negative influence on turnover intention among } \\ \text { Gen Y employees. }\end{array} \\ & H_{a 4}:\end{aligned}$

\section{LITERATURE REVIEW}

\section{A. Generation Y}

Generation Y or Millennial is the people who born from the year 1980 until 1999. However, according to Jessica and Linda (2009), Generation Y is defined as the children born from the year 1980 until 2003. They are the children of baby boomers or well known as generation $\mathrm{X}$ who born from the year 1945 to 1964 . According to a recent survey, Gen Y holds the highest number of generation in Malaysian history. It is predictable that about 80 million U.S Millennial and 14.6 Millenial in UK as for the year 2012 (7). In Malaysia, 44\% of the population are the Generation $\mathrm{Y}$ which also achieve the majority of Malaysian history (23).

\section{B. Work Motivation}

In this section, the origin of work motivation was discussed. The purpose of this discussion is to have a precise understanding of the work motivation concept. Motivation theory examines the process of motivation. It clarifies why individuals at work carry on in the way they do as far as their direction and the headings they are taking. Historically, the word motivation is derived from motive that is a Latin words motivus or movere, which means moving or to move around (5). 
This research would like to highlight that the ground theory of this research related to work motivation is based on Herzberg theory. The hygiene factors, which are generally concerned about the workplace, can be clarified through Abraham Maslow's Hierarchy of Needs. Then again, the initial three needs compensation, nature of the job and interpersonal relationship are all in the hygiene factor of Herzberge's Theory. This reveals to us that the hygiene needs are for the most part the essential needs of people. This similarity of Herzberg's Theory and the Hierarchy of Needs demonstrates that Herzbergee $\mathrm{s}$ Theory is unique in relation to Maslowes just in the technique for categorisation.

Herzberg classifies essential needs of people as hygiene factors. This implies fundamental needs do not give inspiration however just make a helpful workplace. There would be no disappointment among laborers when fundamental needs are satisfied, yet it does not spur them or give them fulfillment, it just evacuates disappointment. The inspiration factors triggers nature of the job where the two best needs of the hierarchy which is regard needs and self-realization needs. These needs give workers fulfilment when satisfied.

Thus, it is easier to apply Herzberg's Theory compare with other work motivational theories. J.S Adams Equity Theory of Work Motivation (1975), Behavioral Modification Theory of Work Motivation (1985), McClelland's Achievement Need Theory of Work Motivation, Rational-economic Model of Work Motivation (2009), Self-actualizing Model of Work Motivation (1970) only highlights certain specific work motivation factors of employee turnover.

Hence, Herzberg theory is well fits the objectives of this study because this theory able to highlight comprehensively the dominating factors in past studies which are extrinsic factors (compensation, interpersonal relationship) and intrinsic factor (nature of job) as the indicator for an employee to be demotivated and leave the workplace.

\section{Turnover}

There are four types of turnovers namely voluntary, involuntary, functional and dysfunctional. However, this research only focused towards the voluntary turnover because it is initiated by the employees. It occurs when an employee voluntarily resign his or her job from the organization and end the service There are several reasons for voluntary turnover such as better job offer, staff conflict, or lack of advancement opportunities.

The Unfolding Model is one that has been starting late made and is getting affirmation into the turnover composing (17). This incipient model was created by Thomas W.Lee and Terence R.Mitchell in 1994 and is perceived as the Unfolding Model. This model takes what was shown in Mobley's Model (1977) and presents another perspective on the turnover system that is exceptional in connection to what Mobley Model (1977) depicts. Mobley's Model (1977) first begins with the possibility that the worker assesses their job when choosing to stop.

Based on the Unfolding Model, employees do not just arbitrarily assess their job unless there is a circumstance that gives them motivation to assess their present position (17). Social Model of Work Motivation (1975) and

This model was the research ground to conduct this study related to turnover. The model tends to explain and cover comprehensively on employee turnover studies and work motivation factors, which describes different psychological paths that people take when quitting organizations. This model also specifically put emphasis on the compensation factor, nature of the job factor and interpersonal relationship factor which affect the decision making of an employee to leave the country. Hence, this model fits to guide this study further to unearth the intention of Gen Y employees to quit their job.

\section{RESEARCH OBJECTIVES}

The objectives of this study are:

1. To identify the level of work motivation among Gen Y employees.

2. To identify the level of turnover intention among Gen Y employees.

3. To identify the difference of work motivation based on gender among Gen Y employees.

4. To determine the influences of Work Motivation factors (compensation, nature of the job and interpersonal relationship) on Turnover Intention among Gen Y employees.

\section{RESEARCH METHOdOLOGY}

In this study, there are two kinds of research design, which are descriptive research and correlational research. Descriptive refers to research studies that have their main objective of the accurate portrayal of the characteristics of persons, situations or groups (20). Whereas, correlational design was used to measure the relationship between independent variable (work motivation) and dependent variable (turnover intention). This study adopts quantitative type of cross sectional study where it provides a snapshot of the distribution of factors and outcomes in a population at a specified period of time.

Participants in this study were 108 Gen Y employees (64 males, 44 females). Based on the level of education, the highest categories of respondents were degree holders $(50.9 \%)$. The employee's working status possessed by junior level with $63 \%$. The respondents were selected through stratified random sampling from 150 operational levels of Gen Y employees from seven main departments in the company selected. The departments consist of Production (29 workers) Warehouse (21 workers), SQE (20 workers), IQC (11 workers), Training (9 workers), HR(10 workers), and Facilities ( 8 workers).

In this study, a set of instrument was administered to each respondent. The instrument divided into three parts consist of 25 items. Section A of the instrument contains demographic questions. Section $\mathrm{B}$ divided into three sub-parts to measure work motivational factors. Five items about compensation (6), eight items measure nature of job that associated with job content (28), and there are three items are used to measure interpersonal relationship (organization support). Section $\mathrm{C}$ was adopted five items from turnover intention questionnaire (22). 
The pilot test conducted showed that the Cronbach's alpha for all the variables have adequate internal consistency in the present study with Cronbach's alphas of .77 for the compensation, .74 for the nature of job and interpersonal relationship, and .84 for the turnover intention.

\section{FINDINGS}

\section{A. Initial Data Analysis}

The SPSS version 19 software was used to analyse the data. Table I illustrated the overall mean values (M) and standard deviation (SD) analysis on work motivational factors using the descriptive statistical method. Findings showed that compensation $(\mathrm{M}=3.00, \quad \mathrm{SD}=0.82)$ and interpersonal relationship $(\mathrm{M}=2.97, \mathrm{SD}=1.04)$ are at moderate level. However, the mean score obtained by the respondents for nature of job factor was 2.26, which is at low level. In conclusion, the compensation factor obtains the highest mean and the work motivation is at a moderate level $(\mathrm{M}=2.52$, $\mathrm{SD}=0.58$ ).

Table-I: Level of work motivational factors and turnover intention

\begin{tabular}{|l|l|l|l|}
\hline Variables & SD & Mean & Level \\
\hline Work Motivation & 0.58 & 2.52 & Moderate \\
Compensation & 0.82 & 3.00 & Moderate \\
Nature of Job & 0.97 & 2.26 & Low \\
Interpersonal Relationship & 1.04 & 2.97 & Moderate \\
Turnover Intention & 0.77 & 4.00 & High \\
\hline
\end{tabular}

\section{B. Findings on the Difference of Work Motivation based on Gender}

Independent t-test was used to measure the work motivation based on gender. Table II showed that there was no significant difference of work motivation among GenY employees based on gender $(\mathrm{t}=-.485, p>.05)$. This was because the $p$ value was .423 , which was greater than significant level of .05 . This result also showed that the mean value of male $(\mathrm{M}=2.99)$ was greater than female $(\mathrm{M}=2.93)$ by small differences of 0.06 . Thus, the null hypothesis $\left(H_{01}\right)$ stated that there is no significant difference of work motivation based on gender among Gen Y employees was not rejected.

Table-II: Work motivation based on gender

\begin{tabular}{lcccc}
\hline Group & N & Mean & $\boldsymbol{t}$ & $\boldsymbol{p}$ \\
\hline Male & 64 & 2.99 & -.485 & .423 \\
Female & 44 & 2.93 & & \\
\hline
\end{tabular}

\section{Findings on the Influence of Work Motivation on Turnover Intention}

Table III depicts the results of the hypotheses testing. The assumptions of multiple regression have been satisfied for all the hypotheses. Based on Table III, hypotheses $H_{a 2}$ to $H_{a 4}$ are tested at the .05 significance level. The findings of study showed that R square was .013 with the significant value of .000. In other words, the three factors of work motivation explains $1.3 \%$ of the variance (R-Square) in turnover intention among Gen-Y employees. The F statistics, F $[(3,15)$ $1.300, \mathrm{p}<.001]$ computed for the significance of multiple $\mathrm{R}$ is .457 , reaches statistical significance $(p=.000)$.

To identify if the overall regression model is significant, the $p$-value is compared to a significance level (.05). This finding shows that the $p$-value (.000) is less than the significance level in which the regression model fits the data better than the model with no predictor variables. The predictor variables in the model has improved the fit of the model.

However, in particular, the three factors of work motivation such as interpersonal relationship $(\beta=-0.41$, $p>.05)$, compensation $(\beta=-0.21, p>.05)$, and nature of the job $(\beta=0.102, p>.05)$ did not have significant influence on turnover intentions of Gen $\mathrm{Y}$ employees. Hence, the hypotheses in this study are not supported by $H_{a 2}, H_{a 3}$, and $H_{a 4}$.

Table-III: Summary of regression model for work motivational factors predicting turnover intention

\begin{tabular}{|l|c|c|c|c|}
\hline Model & R & R square & F & $\begin{array}{l}\text { Sig.F } \\
\text { Change }\end{array}$ \\
\hline 1 & 0.114 & 0.013 & .457 & $.000^{*}$ \\
\hline
\end{tabular}

Coeefficients

\begin{tabular}{|l|l|l|l|l|l|}
\hline Model & $\begin{array}{l}\text { Standardized } \\
\text { Coefficients }\end{array}$ & \multicolumn{4}{|c|}{ Correlations } \\
\hline & \multicolumn{1}{|c|}{ Beta } & $\boldsymbol{t}$ & Sig & Part & $\begin{array}{l}\text { Part } \\
\text { (square) }\end{array}$ \\
\hline Compensation & -.21 & -.208 & .836 & -.020 & .0004 \\
\hline Nature of Job & .102 & 1.05 & .298 & .102 & .0100 \\
\hline $\begin{array}{l}\text { Interpersonal } \\
\text { relationship }\end{array}$ & -.41 & -.417 & .678 & -.041 & .0017 \\
\hline
\end{tabular}

Note: Significant level, ${ }^{*} p<.05$

\section{DISCUSSION}

\section{A. Discussion on the Level of Work Motivation and Turnover Intention}

In this study, it was found that Gen $\mathrm{Y}$ employees moderately motivated to work because of the compensation factor where they believe that their salary is fair for the work they do. Compensations such as rewards, incentives, benefits and salary can serve the purpose of attracting prospective job applicants, achieving human resource objectives and obtaining competitive advantage (3).

The result of this study also can be related to the nature of job among Gen Y employees where past studies had found that Gen $\mathrm{Y}$ is considered to be the least expensive employee to hire, especially in terms of the benefits (12). This shows that Gen $\mathrm{Y}$ employees do not expect a high value of compensation.

Meanwhile, their interpersonal relationship also contributes to decrease their work motivation level although it stands at moderate level. Interpersonal relationship factor which influence work motivation, implies that most of the problems which adversely affect effective functioning of organization are human relationship problems. 
The level of turnover intention among Gen Y employees in the targeted company in this study is high. The employees often think of leaving the organization and waiting for a better job offer in order to quit from the current company. This is an expected finding because, most of Johoreans are willing to live and work in Singapore due to high pay and better working opportunity (14). In conclusion, the level of work motivation is moderate and the level of turnover intention is high among Gen Y employees.

\section{B. Discussion on the Difference of Work Motivation based on Gender}

The objective of this study is also to identify any significant difference of work motivation based on gender among Gen Y employees. The result shows that there is no significant difference of work motivation based on gender. Work motivation is merely the same for both female and male employees.

This finding is consistent with previous studies conducted by researchers. For instances, there is no significant correlation between gender and employees' work motivation (27). In addition, work motivation between men and women are equally attainable (10). This result may be due to both females and males employees seek to self-actualization in their career developments. In conclusion, the objective of the research was answered with no significant difference of work motivation based on gender among Gen Y employees.

\section{Discussion on the Influence of Work Motivation on Turnover Intention}

This study was undertaken to develop a better understanding of the influence of work motivation on turnover intention among Gen Y employees. The findings of this study suggest that work motivational factors did not exert significant influence on turnover intentions of employees. In particular, the factor of compensation factor did not exert significant negative influence on turnover intentions of employees. This finding of study was not in line with a previous study. For instance, the embracement in compensation factor can influence on low turnover intention and vice versa (12).

Next, the factor of interpersonal relationship also did not have significant influence on turnover intentions of employees. The embracement in interpersonal relationship factor does not necessarily lead to low turnover intention. This finding of study is not in line with the view of the collectivism cultural orientation, where it could be argued that social rewards are vital to Gen Y employees. If such social work values are not realized by them, they will experience less fit, and eventually, this will influence their decision to leave the organization (7).

The results of this study also revealed that the factor of nature of the job did not have influence on turnover intentions of Gen Y employees. The finding was not consistent with the findings of study conducted by a past researcher (15) in which the characteristics of an organic system emerge as the favored form by employers and workers.

\section{IMPLICATIONS AND SUGGESTIONS}

In conclusion, our findings did not show any influence of three work motivational factors on turnover intention of Gen $\mathrm{Y}$ employees. This might be attributed to the context of the study and it needs further investigation. We also acknowledged some limitations of the present study and the need for further research.

Firstly, this study is limited to a sample of Gen Y employees in the district of Johor Bahru, Johor. Thus, the results may be limited in their generalizibility, for example, to other employees in Malaysia. Considering the evidence from previous research and the present study, a future study is recommended to replicate these findings with more samples and wider context. In other words, future studies could use a diverse sample, for example employees from other regions or even other levels in order to gain better understanding of the relationship between work motivational factors and turnover intention among employees in Malaysia.

Secondly, the quantitative survey method also lacked the depth of explanation regarding the turnover intentions of the Gen Y employees. Therefore, future studies may emphasis on other alternatives to measure work motivational factors and turnover intention such as using a separate qualitative research based on the employees' points of view. For instance, an open-ended interview with employees can be employed by future studies. Thus, results obtained will be more accurate and precisely.

Finally, future studies may focus on public sectors as well as non-manufacturing industries such as textile industry, communication industry, and societies industry that might be experience the similar issues of turnover rate. Other than that, this study only put emphasis on operational level workers that largely influence the rate of turnover in the company. It can be interesting that future studies can look deeper into the difference between managerial or non-managerial Gen $\mathrm{Y}$ employees' intents to leave. An examination of managers and non-managers perspectives would probably create different views of an intention to leave a job in the manufacturing industry.

\section{CONCLUSION}

As a conclusion, this study reveals that the level of work motivation is moderate and the level of turnover intention is high among Gen Y employees. The result also shows that there is no significant difference of work motivation based on gender among Gen Y employees.

This study also reveals that work motivational factors such as compensation, nature of job and interpersonal relationship did not have significant influence on turnover intention among Gen Y employees. This study will be useful for references that are related to manufacturing and future research in terms of work motivational factors and turnover intention.

\section{REFERENCES}

1. Abbasi, S. M., \& Hollman, K. W. (2000). Turnover: The Real Bottom

2. Line. Public Personnel Management, 29(3), 333-342. 


\section{The Influence of Work Motivation on Turnover Intention among Gen Y Employees}

3. Abdelbaset. Q, Fadzilah. W, Zakaria. S. 2015). Generation - Y turnover intention in business process outsourcing sector. International Conference of Management: Kota Kinabalu, Sabah, Malaysia.

4. Bratton, J. \& Gold, J., Human resource management: Theory and practice, 2007, 4th edition, Palgrave: Basingstoke.

5. Chong, Y. O., Keh, C. G., Tan, Y. T., Lim, Y. H. \& Tho, M. S. (2013). Propensity to work abroad amongst generation $\mathrm{Y}$ working adults in Malaysia. Proceeding of the International Conference on Social Science Research, 695-705. Retrieved April 25,2014,

6. Colman, M. M., \& Carron, A. V. (2001). Investigating the Mediational Relationship of Leadership, Class Cohesion, and Adherence in an Exercise Setting. Small Group Research, 32(5), 558-575.

7. Cook, J. D., Hepworth, S. J., Wall, T. D., \& Warr, P. B. The experience of work, 1981, London: Academic Press.

8. Dzimbiri, L. B. Organization and management theories: An African focus. Retrieved on 28 December 2019, from http://books.google.com. my/books.htm.

9. Debunking the Millennial Myth (2012), Retrieved December on 12,2017from

http://static1.squarespace.com/static/53960212e4b0d0ce554555d9/t/5 55659b9e4b0c9f33190ec68/1431722425018/Debunking+the+Gen+Y +Myth.pdf

10. Gallup (2016), Global Great Jobs Report. Retrieved on 1 December 2017 , from

https://news.gallup.com/reports/190922/gallup-global-report-great-jobs -2016.aspx

11. Gino, F., Wilmuth, C., \& Brooks, A. W., Compared to men, women view professional advancement as equally attainable, but less desirable. Proceedings of the National Academy of Sciences. 2015, In press.

12. Grant, A. M., \& Gino, F. (2010). A little thanks goes a long way: Explaining why gratitude expressions motivate prosocial behavior Journal of Personality and Social Psychology, 98.

13. Henry, A. (2006). Motivating \& managing different generations at work. Retrieved December on 12, 2017, from Mskills: http://www.mskills.com.au/DownloadManager/downloads/ Manuf2020_Avril\%20Henry.pdf.

14. Henly, J. R. 2000. Mismatch in the low-wage labor market: Job search perspective. K. Kaye D. S. Nightingale, eds., The Low-Wage Labor Market. The Urban Institute, Washington, DC, 145-167.Iwu, J. (2016) Influence of digital literacy on career progression and work motivation of academic library staff in South-West, Nigeria: Library Philosophy and Practice.

15. Juanji, Y. (2011). Reproducing class in a global labour force: The case of Singapore's Division of labour: The University Of British Columbia

16. Jean. M.P., Organizational behavior: Managing people and organizations. 2008, Business \& Economics Management: Cengage Learning.

17. Jones. A., (2011) Globalization: Key Thinkers, Polity: Cambridge, UK and Malden, MA, 2010; 260 pp.: ISBN 9780745643212, £50.00 (hbk), ISBN 9780745643229, £15.99 (pbk). International Sociology, 26(2), 279-279.

18. Lee T. W. \& Mitchell T. R. 1991. The Unfolding Effects of Organizational Commitment and Anticipated Job Satisfaction on Voluntary Employee Turnover. Motivation and Emotion, 15 (1) 99-121.

19. Muldoon, O. T. and Kremer, J. M. D. (1995), Career aspirations, job satisfaction and gender identity in female student nurses. Journal of Advanced Nursing, 21: 544-550.

20. Pascual, R., \& Andersson, P. H., Facilitating student motivation in engineering education through active learning methods, 2012, Working paper series of Pontificia Universidad Católica de Chile.

21. Polit, D.F, \& Hungler, B.P., Nursing research : Principles and methods. 2004, Aurora,IL,USA: Lippincott Williams \& Wilkins.

22. Shahid \& Chavakkad. (2009). A Study on employee motivation in Hyderabad Industries. Retrieved 20 November 2012, from http://www.scribd.com/doc/13317890/A-Project-on-EmployeeMotivati on- by Shahid-Kv-chavakkad.

23. Sok Nee, C et al., A Study Of Employees' Turnover Intention among Generation $Y$ in Fastfood Industry, 2013, Unpublished Undergraduate Project, Universiti Tunku Abdul Rahman.

24. Tansel, A. \& Gungor, N. D. (2003). "Brain drain" from Turkey: Survey evidence of student non-return. Career Development International, 8(2): 52-89.

25. The Star (2017), retrieved on 2 December 2017 from https://www.thestar.com.my/.
26. The World Bank. (2012). "Selected World Development Indicators," Retrieved on May, 1st, 2017 at http://data.worldbank.org/sites/default/files/wdi-2012-ebook.pdf,on Oct. 1, 2013.

27. The Ultimate Guide to Malaysian Gen Y. (2016), Retrieved 20 November 2017 https://daily.wobb.co/education/ultimate-guide-malaysian-gen-y

28. Ufuophu-Biri, E., \& Iwu, C.G. (2014). Job Motivation, Job Performance and Gender Relations in the Broadcast Sector in Nigeria. Mediterranean Journal of Social Sciences, 5(16).

29. Van den Berg, P., \& van der Velde, M. (2005). Relationships of functional flexibility with individual and work factors. Journal of Business and Psychology, 20, 111-129.

30. Zhao, H., Seibert, S. E., \& Hills, G. E. (2006). The mediating role of self-efficacy in the development of entrepreneurial intentions. Journal of Applied Psychology, 90, 1265-1272.

\section{AUTHORS PROFILE}

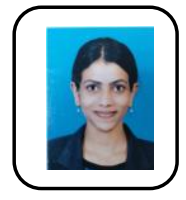

Komalaa Naaidu is presently a Recruitment Consultant in Agensi Pekerjaan Inter Island (Sdn Bhd). She has completed her Master in Human Resource Development Universiti Teknologi Malaysia (UTM) and Bachelor Degree in Employment Law in Universiti Malaysia Sarawak

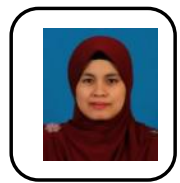

Dr Mastura Mahfar is a senior lecturer in psychology and counselling in the School of Human Resource Development and Psychology at Universiti Teknologi Malaysia. She holds a PhD in Guidance and Counselling from Universiti Putra Malaysia. Her research interest includes stress intervention and workplace counselling. She teaches counselling and psychology courses and supervises master and doctoral projects within these fields. 